\title{
Uninsurable Risks of Floods, Deluges, Overflows and the System of Solution ${ }^{\#}$
}

\author{
Hana BÁRTOVÁ* - Karel HANZLÍK ${ }^{* *}$
}

Uninsurable risks mean actual lack of commercial solution of risk realization by insurance market, especially in the case of floods, deluges and overflows, which play a specific role in conditions of the Czech insurance market. Importance of flood solution is caused by repetitive flood occurrence in the Czech Republic. Nevertheless there is no effective commercial solution provided by insurance companies. Due to these key factors mentioned above this paper is dedicated to uninsurable flood risks and to commercial way, which is possible to solve all related problems.

Main aim of the paper is to define conditions of commercial insurance system, which is able to cover uninsurable flood risk. Our solution is focused on households and their property, which are negatively influenced by repetitive flood risk realization and subsequently by avoidance of insurance protection by existing commercial insurance products. The system is supposed to be profitable.

In order to reach main aim is necessary to define a functional commercial system, which is effective in the way of uninsurable risk solution. An integral part of the paper consists of gross premium calculation. Our approach is designed according to special conditions of the Czech insurance market. Similar solutions of enormous flood risks are also known in foreign countries. In spite of different factors of each insurance market, this paper describes foreign approach of flood risk solution applied abroad.

The first part of the paper is focused on description of commercial System Solution of Uninsurable Flood Risks. The next part consists of

\# The article is processed as an output of a research project System Solution of Uninsurable Risks with Focus on Floods registered by the Internal Grant Agency of The University of Economics, Prague under the registration number F1/8/2013.

Ing. Hana Bártová - PhD student; Department of Banking and Insurance, Faculty of Finance and Accounting, University of Economics, Prague, W. Churchill Sq. 4, 130 67 Prague 3; Czech Republic; 〈hana.bartova@vse.cz>.

** Ing. Karel Hanzlík - PhD student; Department of Banking and Insurance, Faculty of Finance and Accounting, University of Economics, Prague, W. Churchill Sq. 4, 130 67 Prague 3; Czech Republic; <karel.hanzlik@vse.cz〉. 
gross premium calculation, which is in detail explained in order to respect specific conditions of the Czech insurance market. The last part shows you another approach of uninsurable flood risk solution. As an example we have chosen the National Flood Insurance Program of the US, which is compared with our commercial solution in according to the Czech insurance market.

Important part of our uninsurable flood risk solution is based on gross premium calculation. All results assume domestic conditions, development and specific factors of the Czech insurance market. For the purpose of premium calculation we use available real data provided by the Czech Insurance Association (Česká asociace pojišt'oven) and other information of individual insurance companies. Due to the lack of high quality data of flood risk development in the Czech Republic our calculations is complemented by estimations and simplifications. Premium is calculated by using actuarial methods. We also pay attention to risk profile of Czech insurance subjects and to importance of flood consequences.

Issue of uninsurable risks (especially risks of floods, deluges and overflows) is solved by many authors from different perspectives. Common approach is to take into account presence of the financial market and solutions using financial instruments - Jaffee, Russell (1997). Other approaches are based on recent trends on the world insurance market Daňhel, Ducháčková, Radová (2008), or solution of non-life risks through insurance pool with influence of the state authority and through available opportunities of the commercial insurance market - Ducháčková, Daňhel (2010, pp. 61-126 and 147-214). Finally all of these solutions are considerably affected by climate changes, loss development and changes in society - Čamrová, Jílková (2006, pp. 61-104).

\section{System Solution of Uninsurable Flood Risk}

Trends on global insurance market are influenced by claims development. Characteristic features in conditions of the Czech insurance market are claims development and losses caused by floods, deluges and overflows, which appear more often in recent history. This effect is closely related to climate changes and to interventions in landscape as a human decision (Daňhel, Ducháčková, Radová, 2008).

An issue of solving consequences of floods and deluges has two points of view - at national level and at regional level. Czech landscape is typical for its density of rivers and streams. The worst claims development was dated in 1997 and in 2002, which were caused by floods at the national 
level. In 1997 natural catastrophe of flood requested 62.6 billion CZK, which meant $3.3 \%$ GDP. Vast losses almost stopped life in hundreds of municipalities, infrastructure collapsed, countryside was changed. After a wave of solidarity and government interventions the Czech authorities have financed modern rescue system, systematic structure of flood affected areas recovery and they also have organized prevention process. Subsequently widespread floods in 2002 displayed unpreparedness of systems mentioned above, which were in progress and losses exceeded the last enormous flood in 1997. Total flood costs in 2002 were 73.14 billion CZK. It equals to $2.8 \%$ GDP. Reinsurers had covered more than $87 \%$ of insured costs (28.7 billion CZK). Totally the Czech insurance companies paid 32.9 billion CZK to insured clients.

The state has started a process of rescue system implementing, early warning system and process including flood remains recovering. The state authorities have determined a strategic target - to reduce costs on damage removing and to increase expenditure on prevention. Nevertheless partial modifications of anti-flood barriers, aquatic constructions and other arrangements did not solve negative impact on property of inhabitants affected by twenty-year, thirty-year and also hundred-year floods (Čamrová - Jílková, 2006, pp. 61-104). Flood risks haven't been removed and an assumption of commercial insurance application to eliminate subsequent flood costs has come true. The Czech region was considered according to flood risk, recent flood frequency, quantity of loss and probability of risk occurrence. We can distinguish four flood zones. Real estates, which were built in the fourth zone, are uninsurable.

Factors mentioned above have a negative impact on individuals. At present commercial insurance weakens its role in property protection (Ducháčková - Daňhel, 2010). Insurance loses a key position in financial market frame (Sigma, 2011a, 2011b). In spite of increasing expenditure on loss prevention we miss a functional system, which could be used by individuals and owners of uninsurable property. Our solution of uninsurable risks is described in next part of paper.

\section{Multi-Source Fund System}

Our approach of uninsurable flood risk solution is based on 4 key factors

- compulsory participation,

- profitability,

- pool contribution,

- state supervision. 
The system is described as a commercial insurance product in the form of existing product innovation.

To support an interest in a way of uninsurable flood risk solution the system is designed as profitable. The insurers are motivated by improvement of their image or in the form of CSR. A successful system is a balanced mix of key components. It is necessary to make an optimal combination of important factors. Our model consists of 3 main components:

- state,

- insurance companies,

- insurance intermediaries.

An insurance pool creates a core of our system. This pool is designed as a fund serving to save membership payments and fees. Insurance companies are members of the pool. Next to the pool there is an assumption to define a fund structure, which is also formed by state payments, especially in case of negative claims development.

Membership in the insurance pool is compulsory for predetermined group of insurance companies. A condition to entrance into the pool is responsible to an economic activity of insurers. All composite and nonlife insurance companies are members of the pool automatically as far as they provide property and household contents insurance. Participation in the pool is based on compulsory entry fee, which is defined in the level of 10 million CZK. These costs represent a kind of fee, which ensures to insurer to take a part in new market segment. In fact limited number of insurance companies can provide insurance services to clients, whose real estates are situated in the fourth (uninsurable) flood zone. About 30 thousand real estates were built in high risk zone in according to last research. We estimate that number of uninsurable buildings is higher (approximately 100 thousand addresses) because of extension of flood zones. The amount of 10 million CZK per insurer can cover current claims development without pool and fund losses. In case of moderate claims development it is possible to redistribute pool profit between pool members. Pool resources have a special purpose and are strictly determined to cover future flood costs. An exception of strict pool rules makes insurer's potential insolvency.

The system solution uses internal and external network of intermediaries. Using insurers' own distribution channels have neutral impact on premiums because provision and cost schemes are common 
and strictly predetermined. Conversely new product creation and developing of new distribution chain would mean higher costs than using own chain of internal and external intermediaries. Insurers supplement own portfolio of insurance products by risk recovering of estates in the fourth flood zone and cancel existing exceptions of insurance protection.

Fig. 1: Multi-Source Fund System

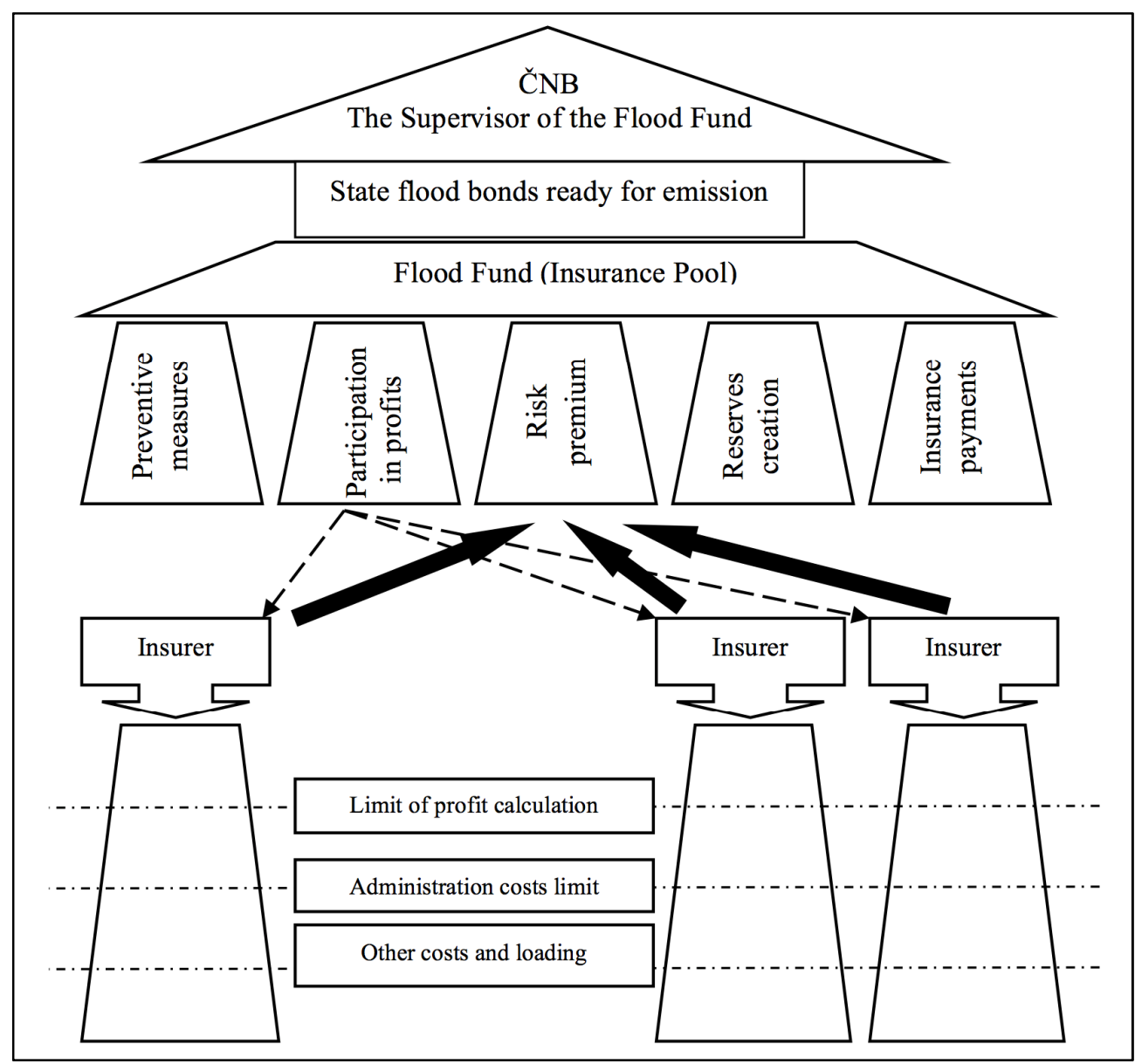

Source: authors.

An administration of insurance policies is in competence of insurers' administrative departments. System uses a service of own network of claims adjusters in case of risk realization. This arrangement contributes to costs reduction and simultaneously to prevent from insurance payments manipulation and to make loss settlement faster. Each of insurers also shares risk costs. A compulsory financial participation in loss removing is 
estimated on the level of $10 \%$ of each insured event. This measure is adequate in comparison with total estimated costs and also supports an assumption of quick claims settlement, which prevent from deferred claims adjustment. Innovation influences positively process of adjustment. Claims adjusters can processed other losses (e.g. household losses) during claims adjustment of flood consequences. Insurers cover these expenditures also in according to avoid of excessive damages and to maintain an effective management of adjusters. An evaluation of adjustment report is in exclusive competence of insurer, who doesn't pay a commission of loss percentage. This solution avoids of problems connected with disproportionate of insurance protection costs.

Important part of the system expresses a role of the state. The state position is designed as independent without interventions into pool operations. This system runs independently till correct creation of reserves, which cover risk development in specified time schedule. Opposed to classic approach of reinsurance markets the state doesn't participate in risk settlement of any loss. The state reinsurance approach corresponds to reinsurance with excedent features, but all claims developments seem as one claim. Debit account is formed up to $100 \%$ of current status of reserves. The state authority simultaneously doesn't participate in each risk and individual loss. In case of the fund overdrafting the state takes control over the situation, provides direct deposits on flood fund account and issues flood obligations. Our suggested system is closed to reinsurance model of loss excessiveness CATXL (CATastrophe eXcess of Loss cover), which is devoted to reinsure cumulative claims. These claims appear very rarely and are described in a form of the same type. A ceding insurer doesn't pay any premiums to the state authority, because these payments are hidden in cash flows into the reserve fund.

\section{Supervision over the Fund}

System's supervision expresses another significant complement of the system. An independent supervisor of the Czech financial system is the Czech National Bank. The supervisor plays a major reinsurance role also in our system solving uninsurable risks. Model doesn't expect a risk transfer to reinsurance markets. A participation of the Czech National Bank in conditions of the insurance fund is fundamental and this authority supervises over the fund. The Czech National Bank as the integrated financial authority takes a responsibility for smooth fund running, creation of reserves, entrance and controlled fund leaving of pool members. 
In the model the Czech financial system authority also determines fluctuations and flood loading, declares amounts of calculated costs connected with the insurance product and especially controls and takes part in profit redistribution into pool members and fund reserves in case of positive claims development. Redistribution of fund profit shares should be very sporadic. We expect that free reserves and profit will be used in process of anti-flood barriers building to avoid of future repeated catastrophic losses. One of system's aims is prevention and to eliminate compensation payments. Profit should mitigate negative effects caused by floods, deluges and overflows and expenditures on prevention should decrease future fund and pool requirements for policy coverage. Redistributed profit flows to insurers' accounts in according to their pool participation, concretely to risk premiums paid to the fund. These profit flows are supposed to support regions with the highest flood, deluge and overflow risks. Profit transferring is closed to the fact that insurers are participated in costs coverage and it is in their interest to build anti-flood barriers and to finance anti-flood protection in concrete regions. The supervision in compliance with rules to competitive flood tendering is performed by the fund.

Fig. 2: Supervision over the Flood Fund

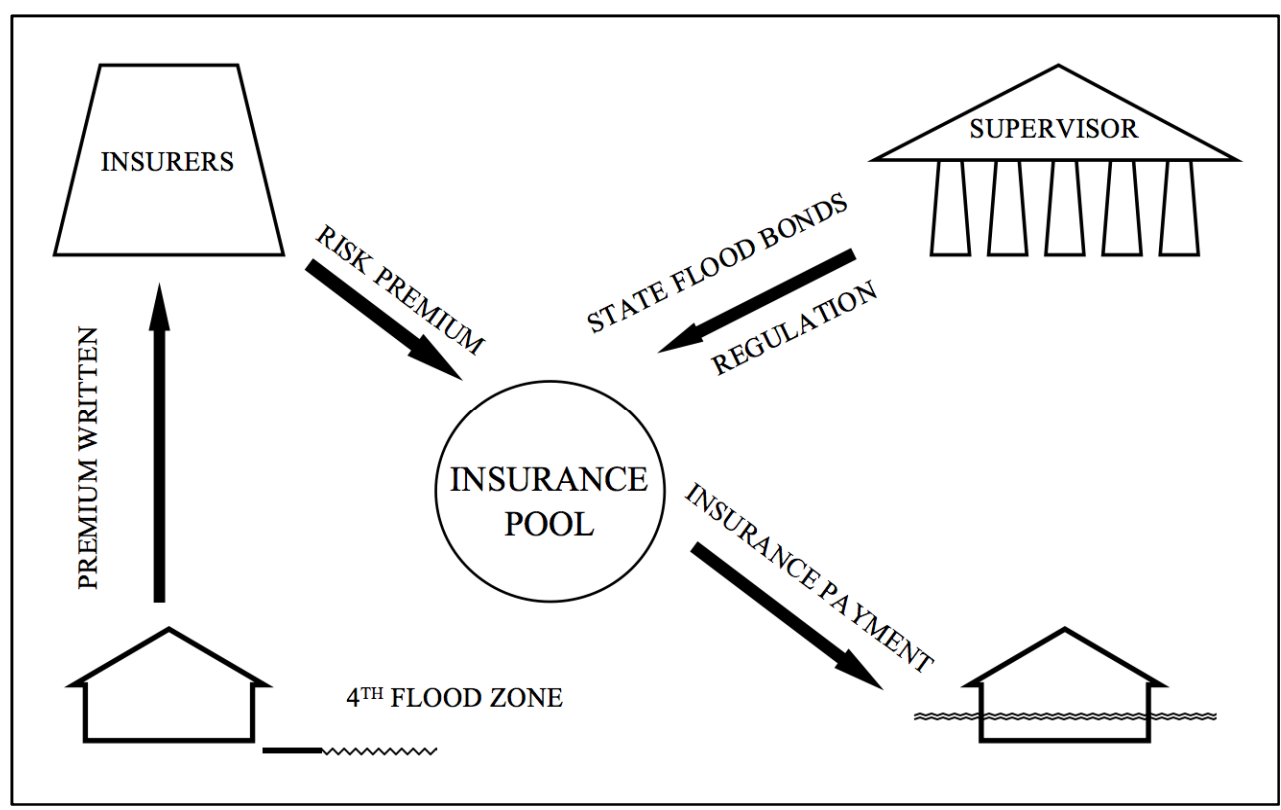

Source: authors. 


\section{Coverage of Uninsurable Risks and Gross Premium Calculation}

Claims development of floods in the Czech Republic is unfavorable. Our model is based on several assumptions, which are described to achieve final form of the fund system. At least 30 thousand of real estates in the Czech Republic are uninsurable thanks for repetitive floods. It is highly probable that the number of uninsurable realties will increase as a result of next wave of risk realization in different flood regions. We estimate that real amount of uninsurable real estates is three times higher and will be extended in the future. Net premiums written of the system solution is calculated on the basis of 100 thousand concluded insurance contracts.

Our model calculates with realty in value of 2 million CZK. It is current purchase price of common Czech family house. Value of real estates is purposely overestimated. In fact the number of insurance events doesn't equal to the number of real estates. E.g. in a block of flats (we suppose a community of block owners) there is possible realization of several insurance cases within one address (in the case of no framework agreement). We also suppose full value of insurance and abstract from unfair practices of policy holders, especially from intentional underinsurance. Tab. 1: Insurance Event as $1 \%$ of Realties Affected by Loss in 1 year
with average sum insured of 2 mil. CZK (in CZK)

\begin{tabular}{|r|r|r|r|}
\hline $\begin{array}{c}\text { Amount } \\
\text { of losses }\end{array}$ & $\begin{array}{c}\text { Individual } \\
\text { insurance } \\
\text { payment }\end{array}$ & $\begin{array}{c}\text { Total } \\
\text { insurance } \\
\text { payment }\end{array}$ & $\begin{array}{c}\text { Insurance } \\
\text { payment after } \\
\text { participation }\end{array}$ \\
\hline 800 & 50000 & 40000000 & 32000000 \\
\hline 110 & 400000 & 44000000 & 39600000 \\
\hline 20 & 600000 & 12000000 & 10800000 \\
\hline 35 & 1000000 & 35000000 & 31500000 \\
\hline 35 & 2000000 & 70000000 & 63000000 \\
\hline $\mathbf{1 0 0 0}$ & & $\mathbf{2 0 1 0 0 0 0 0 0}$ & $\mathbf{1 7 6 9 0 0 0 0 0}$ \\
\hline
\end{tabular}

Source: Cipra (2006, pp. 311-338) and authors calculation.

Assumed flood risk is implemented at least in annual frequency of $1 \%$ of realties. Degree of loss (in according to Tab. 1) is $10.05 \%$ taking into account distribution of loss frequency and loss amount. Average loss 
corresponds to claims development of last 16 years in the Czech Republic (it is considered average insurance penetration and personal property and no business property).

Model degree of loss expresses ratio of average loss and average sum insured. Average loss (amounting to 201 thousand CZK) is determined from amount of total insurance payment and amount of losses due to existing claims development. Determination of net risk premium is based on specified degree of loss. Loss participation is set as a percentage $(10 \%)$ in order to improve motivation to quick loss adjustment. Nevertheless loss adjustment is limited by the lowest amount of 10 thousand CZK, which should decrease a number of administratively demanding minor losses.

Insurance policy holder (person insured) participates in loss together with underwriter, who negotiates of contract. Participation is dealt with absolute franchise to eliminate minor losses. Our main aim is to focus on contingency losses. Supposed function of franchise is to influence positively adjustment of claims.

Next part of premium calculation is described by specified degree of loss. Evaluation of specified degree of loss $\left(q_{2}\right)$ respects relative frequency of individual degree of loss or partial loss.

Tab. 2: Specified Degree of Loss

\begin{tabular}{|c|r|r|r|r|c|}
\hline \multicolumn{1}{|c|}{$\mathbf{Z}$} & \multicolumn{1}{|c|}{$\mathbf{T}_{\mathbf{z}}$} & $\mathbf{t}_{\mathbf{z}}$ & $\mathbf{Y}_{\mathbf{z}}$ & $\mathbf{b}_{\mathbf{z}}$ & $\mathbf{G}_{\mathbf{z}}$ \\
\hline $\mathbf{0 . 1 0}$ & 800 & 0.80 & 0.04 & 0.80 & 0.0400 \\
\hline $\mathbf{0 . 2 5}$ & 110 & 0.11 & 0.01 & 0.91 & 0.0538 \\
\hline $\mathbf{0 . 5 0}$ & 20 & 0.02 & 0.01 & 0.93 & 0.0613 \\
\hline $\mathbf{0 . 7 5}$ & 35 & 0.04 & 0.02 & 0.97 & 0.0831 \\
\hline $\mathbf{1 . 0 0}$ & 35 & 0.04 & 0.03 & 1.00 & $\mathbf{0 . 1 1 3 8}$ \\
\hline & $\mathbf{1 ~ 0 0 0}$ & $\mathbf{1 . 0 0}$ & $\mathbf{0 . 1 1}$ & & \\
\hline
\end{tabular}

Source: Cipra (2006, pp. 311-338) and authors calculation.

Calculation of specified degree of loss is determined by real data and by hypothetical $1 \%$ of flood affected real estates. Calculation is influenced by these parameters $-z$ (interval degree of loss), $T_{z}$ (amount of loss in loss interval), $t_{z}$ (relative frequency in loss interval), $Y_{z}$ (wage degree of loss in loss interval), $b_{z}$ (cumulative and relative frequency of loss in loss interval), $G_{z}$ (wage amount of losses in loss interval). 
Specified degree of loss $\left(q_{2}\right)$ within available information is determined on the level of $11.38 \%$.

\section{Net Premium Calculation}

To calculate net premium it is necessary to choose a level when total insurance payment is equivalent to premium collected. We search for an amount of premium, which is enough to all claims adjustment generated during a calendar year. This process is based on principle of equivalence. Net premium calculation in this system depends on full value insurance. Our solution abstracts from underinsurance, which is caused by intentional or unintentional miscalculation of sum insured by insurance consumer or insurance intermediary. We conclude an equality assumption of actual value and sum insured. Effectiveness of insurance coverage is equal to 1 due to our net premium calculation.

Calculation of non-participating net premium in our model is based on technical rate of interest in amount of $2 \%$, which expresses estimated current interest level in market conditions of the Czech Republic. Amount of non-participating net premium is equal to $2253 \mathrm{CZK}$.

$$
{ }^{S} P_{(h)}^{H}=v \cdot q_{1} \cdot q_{2} \cdot S,
$$

where $P=$ net premium,

$S=$ sum insured,

$H=$ insurance value (supposed to $h=H$ according to full value insurance),

$h=$ ratio of insurance value and actual value,

$v=$ discount rate $(0.990)$,

$q_{1}=$ loss frequency,

$q_{2}=$ specified degree of loss.

In case of excess participation on the level of $10 \%$ (at least 10 thousand CZK) net premium equals to $1422 \mathrm{CZK}\left({ }_{E P}^{S} P_{(h)}{ }^{H}\right)$. It follows rate calculation of net premium with excess participation in amount of $0.0711 \%$. We deduct own participation, which is covered by person insured. Calculation is shortened due to assumption of correct sum insured adjustment in according to insured value.

$$
\underset{E P}{S} P_{(h)}^{H}=v \cdot q_{1} \cdot\left[G_{1}+\left(1-b_{1}\right) \cdot s-G_{0.1}-\left(1-b_{0.1}\right) \cdot x_{0}\right] \cdot H,
$$

where $s=$ full value insurance, 
$x_{0}=$ ratio of contracted sum insured and insurance value.

\section{Gross Premium Calculation}

Calculation of gross premium conforms to current requirements to cover fluctuations of insurance payments and to include administration costs, commissions, adjustment costs and other fees. Net premium with excess participation in amount of $1422 \mathrm{CZK}$ is correct in case of steady and calm claims development. In case of claims deterioration it is necessary to calculate fluctuation reserve, which serves to unexpected increase in insurance events (in the Czech conditions it means fifty-year and hundred-year floods). Fluctuation reserve and net premium create risk premium rate, which takes into account fluctuation in loss distribution and sudden events. Gross premium consists of net premium, safety loading, administration costs and profit calculation of insurer.

Net premium is based on input parameters and assumptions mentioned above. Essential risk premium is extended by fluctuation loading in according to cover fluctuations in long term. Our calculation uses distribution of losses caused by floods. Risk loading calculation considers 30 thousand uninsurable units and models real fluctuations in recent years in the Czech Republic. In order to high probability of risk realization out of current loss interval, we have complemented risk premium rate additionally by safety loading of the fourth flood zone.

Tab. 3: Calculation of Safety Loading

\begin{tabular}{|c|c|r|r|}
\hline $\mathbf{z}$ & $\mathbf{z}^{\mathbf{2}}$ & \multicolumn{1}{|c|}{$\mathbf{T}_{\mathbf{z}}$} & $\mathbf{z}^{\mathbf{2}} * \mathbf{T}_{\mathbf{z}}$ \\
\hline $\mathbf{0 . 0 5 0 0}$ & 0.0025 & 800 & 2.00 \\
\hline $\mathbf{0 . 1 2 5 0}$ & 0.0156 & 110 & 1.72 \\
\hline $\mathbf{0 . 3 7 5 0}$ & 0.1406 & 20 & 2.81 \\
\hline $\mathbf{0 . 6 2 5 0}$ & 0.3906 & 35 & 13.67 \\
\hline $\mathbf{0 . 8 7 5 0}$ & 0.7656 & 35 & 26.80 \\
\hline & $\mathbf{1 . 3 1 5 0}$ & $\mathbf{1 0 0 0}$ & $\mathbf{4 7 . 0 0}$ \\
\hline
\end{tabular}

Source: Cipra (2006, pp. 311-338) and authors calculation.

Calculation of risk loading is essentially stricter because model is based on the highest risk units. We benefit from the presumption that $10 \%$ of estates are affected by insurance event of total loss (2 million CZK) once per fifty years. In order to cover these fluctuations it is necessary to collect net premium in the amount of 5.4 billion CZK during 
50 years (after deduction of participation amounting to $10 \%$, which means $5400 \mathrm{CZK}$ of loading for estate in value of 2 million CZK). Model meets this requirement through flood loading in the amount of $1.8 \%$.

$$
\begin{aligned}
& r p=P+\left(\frac{4}{N} \cdot \sqrt{\sum z^{2}}+f_{l}\right) \cdot H, \\
& r p=1421.64+\left(\frac{4}{30000} \cdot \sqrt{1.3150}+0.0018\right) \cdot 2000000,
\end{aligned}
$$

where $r p=$ risk premium,

$P=$ net premium (with excess participation),

$N=$ estimated amount of insurance contracts,

$f_{l}=$ flood loading.

Risk loading is purposely overestimated and limited by 30 thousand units, which are significantly influenced by risks of the fourth flood zone. Importance of risk loading is overvalued through integration of higher than average sum insured. Risk premium is amounting to $5327 \mathrm{CZK}$, which takes into account selected value of estates ( 2 million CZK). Risk premium included margin of safety in the form of flood loading is estimated on the level of $73.3 \%$. Calculation includes net premium with excess participation $(P)$, number of units in the fourth flood zone $(N)$, insurance value $(H)$ and degree of loss sum of squares $\left(z_{i}^{2}\right)$. Total amount of premium is $5327 \mathrm{CZK}$ and insurance risk premium rate is calculated in the amount of $2.66 \%$.

Our model defines administration costs purposely as a minimum of gross premium. We estimate that the highest administration costs should be acquisition. Other kinds of these costs are mostly joined with claims adjustment. Administrative burden should be minimized due to the fact, that our insurance product is designed as additional insurance to existing products. Higher costs are expected in relation to the fund (in the form of transfers, statement of account etc.), to intermediary (acquisition expenses), to claims adjusters. Profit calculation is in the form of reserve serving to some increased expenses within administration. Primarily the main aim is not to achieve a profit, but to extend insurance protection. Profit flows from the fund in case of moderate claims development.

We can distinguish independent and dependent administration costs. Independent costs are indifferent to the amount of sum insured. We 
estimate these costs at the level of $0.5 \%$. Dependent costs are described in the Tab. 4.

Tab. 4: Dependent Administrative Costs

\begin{tabular}{|l|l|l|c|}
\hline \multicolumn{1}{|c|}{ Type of Cost } & $\begin{array}{c}\text { Space of } \\
\text { Time }\end{array}$ & \multicolumn{1}{|c|}{$\begin{array}{c}\text { Amount and } \\
\text { Origin of Cost }\end{array}$} & $\begin{array}{c}\text { Loading for } \\
\text { Management } \\
\text { Expenses }\end{array}$ \\
\hline Acquisition $\left(\boldsymbol{a}_{\boldsymbol{z}}\right)$ & 1 year & $5.0 \%$ of rate & $0.193 \% o$ \\
\hline Own Administrative $\left(\boldsymbol{d}_{\boldsymbol{z}}\right)$ & permanent & $0.1 \%$ of rate & $0.004 \% o$ \\
\hline Organization $\left(\boldsymbol{o}_{\boldsymbol{z}}\right)$ & permanent & $0.025 \%$ of rate & $0.010 \% o$ \\
\hline Collection $\left(\boldsymbol{i}_{z}\right)$ & permanent & $0.75 \%$ of rate & $0.029 \% o$ \\
\hline Cancellation $\left(\boldsymbol{s t}_{\boldsymbol{z}}\right)$ & 1 year & $0.1 \%$ of rate & $0.004 \% o$ \\
\hline Adjustment $\left(\boldsymbol{l}_{\boldsymbol{z}}\right)$ & 1 year & $2.0 \%$ of the fund & $0.077 \% o$ \\
\hline Other $\left(\boldsymbol{x}_{\boldsymbol{z}}\right)$ & permanent & $1.0 \%$ of rate & $0.039 \% o$ \\
\hline Calculation of Profit $\left(\boldsymbol{p}_{\boldsymbol{z}}\right)$ & permanent & $0.5 \%$ of rate & $0.019 \% o$ \\
\hline
\end{tabular}

Source: Cipra (2006, pp. 311-338) and authors calculation.

It is necessary to limit administration and other costs in order to ensure that insurer doesn't hide profit into increased administrative costs. Fixed amount of administrative costs in primary rate is reliable protection against increasing insurance costs.

$$
b=\frac{r p \cdot \cos t \text { rate }}{1-\left(a_{z}+d_{z}+o_{z}+i_{z}+s t_{z}+l_{z}+x_{z}\right)-p_{z}},
$$

where $b=$ gross premium rate at risk premium rate $(r p)$ per unit of sum insured, cost rate $=$ surcharge on risk premium.

Gross premium is determined from ratio of risk premium with independent administrative costs and dependent administrative costs of gross premium with calculated profit of gross premium. Model's gross premium rate is calculated in the amount of $3.016 \%$, which means total increase in premium rate of $0.37 \%$. Finally annual total gross premium equals to $6032 \mathrm{CZK}$ in case of sum insured of $2000000 \mathrm{CZK}$. 


\section{Comparison with Foreign Approach of Uninsurable Flood Risk Solution}

Our solution of uninsurable flood risk responds to special requirements of the Czech insurance market and to key factors among other including habits and Czech traditions. Nevertheless there are some countries, which solve similar problem. Changing climate and huge natural damages cause higher costs of claims development and negatively effect people lives. As an example, to compare our system with foreign approach, we have chosen system of the U.S.

The National Flood Insurance Program (NFIP) means a solution of flood risk in the USA. The Program substitutes standard commercial products, which aren't able to protect effectively lives and property of households, renters and business units. Community of these subjects has to participate in the NFIP and is also supposed to meet requirements of the Federal Emergency Management Agency (FEMA). The FEMA organizes flood risk protection due to insurance companies. Almost 90 private insurance companies are members of the FEMA and offer effective flood risk protection. Nowadays nearly 21000 communities have taken part in effective system of preventive measures in order to reduce enormous flood causes.

The NFIP is the uniform federal system, which is possible to solve flood consequences and protect against enormous uninsurable risks. Insurance costs calculation includes risk profile of food areas and type of insurance subjects, which are distinguished on building and contents insurance. The NFIP defines 2 areas - high-risk area and moderate-tolow-risk area. High-risk area is probable to be affected by flood at least 1 $\%$ in given year. It equals to $26 \%$ probability of flood occurrence in time period of 30 years. Moderate-to-low-risk area is outside of high-risk area. Flood insurance is voluntary, but owners of property in this area are important beneficiary of flood insurance. About $20 \%$ of the NFIP losses originate from moderate-to-low-risk area. Time periods of current claims are based from duration of mortgages. Buildings and other property in high-risk areas are compulsorily secured by flood insurance.

The NFIP provides insurance protection, which is offered by insurance agents. In case of negative claims development there are 2 the most frequent possibilities of flood consequences solution. The first one is Replacement Cost Value (RCV), which finance replacement of loss. On the other hand Actual Cash Value (ACV) calculates with actual value of 
property at the time of risk realization. This value is reduced by depreciation.

Flood insurance services are calculated at the lowest level of 129 USD per year. These costs cover flood risk in moderate-to-low-risk area and are influenced by a few factors (age of building, number of floors, construction of basements etc.). Flood insurance allows for risk coverage of units or groups of buildings and contents. Limit of coverage is set to buildings property on the level of 250000 USD and to contents of 100000 USD. Flood definition and other important parts of flood insurance policy (deductibles, insurance exceptions etc.) are described by the FEMA.

Preventive measures are enforced by grants, which compensate costs of anti-flood barriers and other measures in order to avoid of repetitive floods. Owners pay increased premium in case of refusing grants. Significant function of the NFIP is represented by flood prevention as a result.

\section{Tab. 5: Comparison of Flood Risk Approaches}

\begin{tabular}{|l|l|l|}
\cline { 2 - 3 } \multicolumn{1}{c|}{} & \multicolumn{1}{c|}{$\begin{array}{c}\text { National Flood } \\
\text { Insurance Program }\end{array}$} & \multicolumn{1}{c|}{$\begin{array}{c}\text { Multi-Source Fund } \\
\text { System }\end{array}$} \\
\hline $\begin{array}{l}\text { Subject of } \\
\text { Insurance }\end{array}$ & $\begin{array}{l}\text { Buildings and contents } \\
\text { (private and } \\
\text { commercial property) }\end{array}$ & $\begin{array}{l}\text { Real estates (only } \\
\text { private property) }\end{array}$ \\
\hline Risk Profile & $\begin{array}{l}\text { High risk and Moderate } \\
\text { to low risk areas }\end{array}$ & $\begin{array}{l}\text { 4th uninsurable flood } \\
\text { zone }\end{array}$ \\
\hline $\begin{array}{l}\text { Organizer/ } \\
\text { Supervisor }\end{array}$ & $\begin{array}{l}\text { Federal Emergency } \\
\text { Management Agency }\end{array}$ & Czech National Bank \\
\hline $\begin{array}{l}\text { Pompulsory } \\
\text { Measures }\end{array}$ & Compulsory & Compulsory \\
\hline $\begin{array}{l}\text { Voluntariness of } \\
\text { Flood Insurance }\end{array}$ & $\begin{array}{l}\text { Compulsory in high- } \\
\text { risk areas (in case of } \\
\text { mortgage provided by } \\
\text { regulated lender) }\end{array}$ & Voluntary \\
\hline Insurance Costs & $\begin{array}{l}\text { Rates including several } \\
\text { factors in the form of } \\
\text { risk premium }\end{array}$ & $\begin{array}{l}\text { Gross premium written } \\
\text { in relation to previous } \\
\text { claims development }\end{array}$ \\
\hline Reimbursement & Replacement Cost & Sum insured reduced by \\
\hline
\end{tabular}


Bártová, H. - Hanzlík, K.: Uninsurable Risks of Floods, Deluges, Overflows and the System of Solution.

\begin{tabular}{|c|c|c|}
\hline & $\begin{array}{c}\text { National Flood } \\
\text { Insurance Program }\end{array}$ & $\begin{array}{c}\text { Multi-Source Fund } \\
\text { System }\end{array}$ \\
\hline Method & $\begin{array}{l}\text { Value or Actual Cash } \\
\text { Value }\end{array}$ & loss participation \\
\hline Intermediary & Insurance agents & $\begin{array}{l}\text { Internal and external } \\
\text { intermediary network }\end{array}$ \\
\hline Coverage Costs & $\begin{array}{l}\text { At least } 129 \text { USD } \\
\text { (moderate-to-low-risk } \\
\text { area) per year }\end{array}$ & $\begin{array}{l}302 \text { USD per year (sum } \\
\text { insured of } 100000 \\
\text { USD }^{1} \text { and the highest } \\
\text { risk area) }\end{array}$ \\
\hline
\end{tabular}

Source: FEMA (2013) and authors.

Solution of uninsurable flood risks is required on international scale. The National Flood Insurance Program provides protection of private and business property and solves consequences of flood risk realization. Similar to Multi-Source Fund System the NFIP deals with preventive measures. Anti-flood prevention is common to both systems. Other similar and also different features are described in the Tab. 5. US solution is based on 2 essential risk areas according to the previous claims development. The Multi-Source Fund System is focused on the highest risk of the forth flood zone, which is established by government and also takes into account flood claims. The Multi-Source Fund System satisfies the requirements of the Czech insurance market and is able to protect usual claims development in the Czech Republic.

\section{Conclusion}

Commercial solution of uninsurable risks with focus on floods, deluges and overflows especially in the conditions of the Czech insurance market is based on pool approach, which should ensure full insurance protection to all participating members and insurance users. Non-life flood risks have significant impact on private and public finance. Claims development influences negatively thousands of the Czech residents and value of their property. Our research highlights the importance of uninsurable risks solution in order to protect final consumers of commercial insurance and also to prevent from high losses and devastating consequences of flood risk realization.

1 Estimated exchange rate equals to 0.05 USD/CZK. 
Model of Multi-Source System Solution is used on our assumptions and available data. In conditions of the Czech insurance and financial markets there is neither public nor private completed database. Due to this data unavailability our research is based on an incomplete database, which hasn't been verified by uniform system. A lack of high quality data is supplemented by our estimations. Relevant data access is the main factor, which participates in final version of our model. Gross premium calculations are based on public data, which are published by the interest association of insurance companies (Czech Insurance Association, 2013). All data are also conformed to the real market development in the Czech Republic. Our calculations are related to the lack of high quality input information of the Czech insurance market, which are followed by our estimations of risk development. Final model version depends on a high extent to factors mentioned above.

The System Solution of Uninsurable Flood Risks meets requirement to solve exceptions of insurance protection made by insurance companies. Key parts of our model are represented by commercial insurance companies joined to the flood pool, the state authority, fund supervisor, insurance intermediary network and claims adjusters. All functions of system members are strictly predetermined. The system is supposed to be profitable. This aim is used to increasing demand for proper commercial insurance product.

Our solution is able to cover enormous flood risk development and total losses caused at least by fifty-year flood. In case of excessive risk development the fund reserves cover $10 \%$ of total losses. Calculated risk premium is based on percentage participation of particular insurer. We assume involvement in claims adjustment and immediate loss compensation. Each consumer of flood insurance pays calculated annual gross premium per unit of his property. Insurer payments are provided by pool reserves, which subsequently flow to policyholders in the form of insurance payments in case of claims development. Due to this purpose the insurance pool consists of main parts - risk premium, reserves creation, insurance payments, preventive measures and participation in profits. In case of moderate claims development pool reserves support areas negatively influenced by floods in the past. It should be in insurers own interest to finance anti-flood protection in concrete regions and to avoid of future enormous flood losses. The system also makes conditions to quick claims adjustment with minimum extra costs. We assume own network of claims adjusters as well as own insurance intermediary network with contributions of external intermediaries. On the top of the 
system there is the independent state authority and the supervisor, who represents the integrated financial authority supervising over the fund.

Total gross premium is set at the level of $6032 \mathrm{CZK}$ in case of sum insured of 2 million CZK, which is closed to the fact of current value of particular unit insured. The system solution is designed to conditions of the Czech insurance market and takes into account special domestic factors. In according to our presumptions this solution is possible to be adopted within any insurance market in case of relevant data and particular risk factors consideration. The Multi-Source Fund System is generally similar to some foreign approaches of flood risk solution. Our system is able to protect property due to compliance with flood claims development in the Czech Republic.

\section{References:}

[1] Cipra, T. (2006): Pojistná matematika - teorie a praxe. Praha, Ekopress, 2006.

[2] Čamrová, L. - Jílková, J. (eds.) (2006): Povodňové škody a nástroje $k$ jejich snížení. [on-line], Praha, University of Economics, Prague, c2006, [cited 24 ${ }^{\text {th }}$ October, 2013], <http://www.ieep.cz/download/publikace/pub036.pdf>.

[3] Daňhel, J. - Ducháčková, E. - Radová, J. (2008): Hlavní globální vývojové trendy ve světovém komerčním pojišstovnictví. Ekonomický časopis, 2008, vol. 56, no. 6, pp. 598-606.

[4] Ducháčková, E. - Daňhel, J. (2010): Teorie pojistných trhů. Praha, Professional Publishing, 2010.

[5] Czech Insurance Association (2013): Statistics. Others Natural Hazards 2012-2013. [on-line], Praha, Czech Insurance Association, c2013, [cited 24 ${ }^{\text {th }}$ October, 2013], <http://www.cap.cz/statistics.aspx?t=1>.

[6] FEMA (2013): National Flood Insurance Program. Summary of Coverage. [on-line], Washington, D. C., Federal Emergency Management Agency, c2013, [cited 24 ${ }^{\text {th }}$ October, 2013], <http://www.floodsmart.gov/floodsmart/pages/about/nfip_overview.jsp>.

[7] Jaffee, D. M. - Russell, T. (1997): Catastrophe Insurance, Capital Markets, and Uninsurable Risks. Journal of Risk and Insurance, 1997, vol. 64, no. 2, pp. 205-230. 
[8] Sigma (2011a): Product Innovation in Non-life Insurance Markets. Where Little " $i$ " Meets Big "I". [on-line], Zurich, Swiss Reinsurance Company, c2011, [cited $24^{\text {th }}$ October, 2013], <http://media.swissre.com/documents/sigma4_2011_en.pdf>.

[9] Sigma (2011b): World Insurance in 2010. Premiums Back to Growth - Capital Increases. [on-line], Zurich, Swiss Reinsurance Company, c2011, [cited 24 ${ }^{\text {th }}$ October, 2013], <http://media.swissre.com/documents/sigma2_2011_en.pdf>. 


\title{
Uninsurable Risks of Floods, Deluges, Overflows and the System of Solution
}

\author{
Hana BÁRTOVÁ - Karel HANZLÍK
}

\begin{abstract}
Uninsurable risks have significant impact on expenses of private and public sectors of economy. In spite of several commercial insurance products and high quality of insurance services current trend of insurance industry is set to define exceptions of insurance protection. The highest losses caused by realization of uninsurable risks in the Czech Republic are constituted by consequences of floods, deluges and overflows. Recent history of flood occurrence emphasizes insufficiency of prevention, protection and loss solution. Due to these risk factors we have focused our research on issues of uninsurable risks in conditions of the Czech insurance market.

The system solution is based on fund approach to ensure commercial insurance protection. Multi-Source System Solution of Uninsurable Risks is purposed in the form of fund with participation of the state authority. Our solution depends on pool creation and primarily should cover enormous claims development. Assumption of fund profitability encourages insurer motivation to become a pool member. Important part of research represents calculation of gross premium. Assessment of input data and calculation of premium are based on real published data and conform to real market development in the Czech Republic. Calculations are also based on our estimations of risk development.

This research highlights the importance of uninsurable risks solution. Effective instrument able to protect lives and property is an innovative commercial insurance product. Our commercial solution is a way to strengthen the role of insurance in a field of uninsurable risks. The system solution is designed to conditions of the Czech insurance market and takes into account special domestic factors. We suppose that our solution is possible to be adopted in conditions of any insurance market in case of relevant data and risk factors using.
\end{abstract}

Key words: Flood; Flood fund; Gross premium; Insurance pool; Uninsurable risk.

JEL classification: G22, G28, P11, R11. 